\title{
PENILAIAN KEMAMPUAN PEMECAHAN MASALAH MATEMATIS SISWA SMP
}

\author{
Asep Amam \\ Program Studi Pendidikan Matematika Universitas Galuh, Ciamis \\ Email: amam@unigal.ac.id
}

\begin{abstract}
ABSTRAK
Kemampuan pemecahan masalah merupakan kemampuan fundamental dalam pembelajaran matematika dan merupakan salah satu tujuan utama dari pembelajaran matematika. Artikel ini membahas mengenai kemampuan pemecahan masalah matematis, permasalahan yang sering muncul dikalangan para peneliti adalah sulitnya mendefinisikan, membuat indikator dan soal yang tepat yang dapat mengukur kemampuan pemecahan masalah matematis siswa karena kurangnya pengalaman dan referensi. Secara singkat tujuan kajian ini adalah dapat mendefinisikan kemampuan pemecahan masalah matematis dengan benar, mampu membuat indikator dan soal kemampuan pemecahan masalah matematik SMP dengan tepat. Metode yang digunakan dalam penelitian ini adalah studi literatur. Hasil kajian menunjukan bahwa kemampuan pemecahan masalah matematis adalah kemampuan seseorang dalam menyelesaikan masalah matematis non-routin yang disajikan dalam bentuk soal matematika tekstual maupun kontekstual yang dapat mengukur kemampuan siswa dalam menyelesaikan masalah dengan indikator mampu memahami masalah, merencanakan penyelesaian, melakukan perhitungan dan mengecek kembali hasil perhitungan. kebaruan dari kajian ini adalah pembahasan yang komprehensif mengenai pemecahan masalah matematis. Adapun dampak dari hasil kajian ini diharapkan para peneliti dapat membuat indikator dan instrument soal yang tepat dalam mengukur kemampuan pemecahan masalah matematis siswa.
\end{abstract}

\section{Kata Kunci}

Kemampuan Pemecahan Masalah Matematis 
PENDAHULUAN

\section{Pentingnya kemampuan pemecahan masalah} matematis

Pemecahan masalah dalam matematika merupakan sebuah kemampuan kognitif fundamental yang dapat dilatih dan dikembangkan pada siswa, sehingga diharapkan ketika siswa mampu memecahkan masalah matematika dengan baik maka akan mampu menyelesaikan masalah nyata paska menempuh pendidikan formal. Hampir semua negara maju menempatkan kemampuan pemecahan masalah matematis sebagai tujuan utama dari pembelajaran matematika di sekolah. Karena diprediksi siswa yang memiliki kemampuan pemecahan masalah matematis dengan baik, maka akan mampu berkontribusi terhadap perkembangan perekonomian bangsanya.

Pemecahan masalah matematis dipandang sebagai sebuah tujuan (goal) jika mengacu pada tujuan pembelajaran matematika dalam KTSP maupun NCTM (2000), sehingga melahirkan apa yang dimaksud dengan istilah kemampuan pemecahan masalah matematis siswa, Atau dipandang sebagai alat (tool) dalam menyelesaikan masalah jika pada saat pembelajaran dimulai dengan menyajikan permasalahan, sehingga melahirkan istilah model pembelajaran berbasis masalah.

Dibeberapa negara maju pemecahan masalah matematika memiliki peran yang sangat penting (Anderson, 2009), diantaranya Kurikulum Singapura menempatkan pemecahan masalah sebagai tujuan utama pembelajaran matematika dengan menempatkan lima komponen yang saling berkaitan dalam pemecahan masalah, yaitu: Keterampilan, Konsep, Proses, Sikap, dan Metakognisi.

Kurikulum Hongkong menempatkan pemecahan masalah sebagai alat, sehingga hampir setiap proses pembelajaran dikelas menggunakan pendekatan pemecahan masalah. Kurikulum inggris menempatkan pemecahan masalah sebagai jantungnya matematika dan refresentasi sebagai sebuah siklus proses yang didalamnya terdapat refresentasi, komunikasi-refleksi, interpretasievaluasi, dan penggunaan prosedur analisispenalaran.

Kurikulum Belanda menempatkan pemecahan masalah sebagai sebuah pendekatan pembelajaran, sehingga dikenal istilah RME. Australia menempatkan pemecahan masalah sebagai kemahiran atau kemampuan untuk dapat membuat pilihan, menafsirkan, merumuskan model, menyelidiki situasi masalah, dan berkomunikasi solusi efektif. Finlandia memandang pemecahan masalah dari berbagai sudut pandang: sebagai alat untuk memajukan berfikir matematik, sebagai sarana melakukan pemecahan masalah dan sebagai proses dimana data yang diperoleh sebelumnya digunakan dalam situasi baru dan tidak dikenal.

Fakta dan realita kemampuan pemecahan masalah matematis siswa.

Berikut ini beberapa permasalah yang terjadi berkenaan dengan kemampuan pemecahan masalah matematis siswa di indonesia (Sugiman, Kusumah dan Sabandar 2012):

Masalah Pertama: masih lemahnya kemampuan pemecahan masalah matematik siswa. Salah satu ukuran dalam melihat kemampuan pemecahan masalah matematik adalah hasil tes PISA (program for international student assesment). Indonesia merupakan salah satu negara peserta PISA menurut BALITBANG depdiknas (2007) distribusi kemampuan matematik siswa indonesia dalam PISA 2003 adalah level 1 sebanyak (49,7\% siswa) level 2 $(25,9 \%)$, level $3(15,5 \%)$ level $4(6,6 \%)$ dan level 5-6 (2,3\%).

Pada level 1 ini siswa hanya mampu menyelesaikan persoalan matematika yang memerlukan satu langkah. Secara proporsional, dari setiap 100 siswa SMP di indonesia hanya sekitar 3 siswa yang mampu mencapai level 5-6. Pada level 5 siswa dapat mengembangkan model matematika untuk situasi yang komplek 
serta dapat memformulasi dan mengkomunikasi, menginterpretasi secara logis. Sedangkan pada level 6 siswa dapat mengkonseptualisasi, menyimpulkan dan menggunakan informasi dari situasi masalah yang kompleks serta dapat memformulasi dan mengkomunikasikan secara efektif berdasarkan penemuan intrepretatif dan argumentatif (sugiman et al, 2012).

Masalah kedua, persepsi yang beragam atau keliru terhadap apa yang disebut pemecahan masalah. Sering kali muncul pendapat bahwa pemecahan masalah matematis identik dengan menggunakan rumus matematika. Sebenarnya, soal-soal matematika yang ada pada buku-buku pelajaran tidak selurunya adalah soal pemecahan masalah . dalam buku pelajaran banyak soal yang tujuannya adalah melatih keterampilan berhitung atau keterampilan menggunakan rumus. Secara mudah dikatakan bahwa tidak semua soal matematika merupakan soal pemecahan masalah matematik.

Masalah ketiga, proses pembalajaran yang dapat membimbing dan melatih siswa agar mampu memecahkan masalah masih belum memperoleh porsi yang memadai. Berbagai temuan dilapangan mengiindikasikan adanya kelemahan pelaksanaaan pembelajaran matematika karena pembelajaran tersebut tidak mempersiapkan siswa dalam proses pemecahan masalah. Diantara temuan tersebut adalah 1). Pembelajaran matematika terbatas pada memberi bekal kepada siswa untuk menyelesaikan soal dalam tes (Armanto, 2000), 2). Pembelajaran matematika terpisah dengan pengalaman sehari-hari (Suharta, 2002). 3). Guru matematika mengajar dengan metode tradisional (zulkardi, 2005) 4). Siswa yang mampu memetik ilmu adalah siswa kelompok pandai (Sato, 2007) dan 5). Guru mengajar dimulai dengan definisi dan teorema.

\section{METODE PENELITIAN}

Metodologi yang digunakan dalam penelitian ini adalah kajian literatur dengan menggunakan sumber primer sebagai rujuakan buku utama dan sumber sekunder hasil penelitian empiris dari hasil penelitian pada jurnal internasional bereputasi dan jurnal nasional bereputasi.

\section{HASIL DAN PEMBAHASAN \\ Definisi kemampuan pemecahan masalah matematis}

NCTM (2000) menyatakan bahwa pemecahan masalah memerankan peran ganda pada kurikulum sekolah. Satu sisi adalah sebagai sarana atau alat mendasar untuk mempelajari matematika disisi lainya adalah sebagai tujuan utama dalam pembelajaran matematika.

Montague (2007) mengatakan bahwa pemecahan masalah matematis adalah suatu aktifitas kognitif yang komplek yang disertai proses dan strategi. Niskayuna (1993) menggolongkan tiga intrepretasi pemecahan masalah yaitu 1). pemecahan masalah sebagai pendekatan (Approach): maksudnya pembelajaran diawali dengan masalah; 2). Pemecahan Masalah sebagai tujuan (goal): berkaitan dengan pernyataan dengan mengapa matematika diajarkan dan apa tujuan pengajaran matematika; dan 3). Pemecahan masalah sebagai proses (Procees): suatu kegiatan yang lebih mengutamakan pentingya prosedur langkah-langkah, strategi atau cara yang akan dilakukan siswa untuk menyelesaikan masalah sehingga menemukan jawaban.

Sumarmo (2005: 6-7) mengemukakan bahwa pemecahan masalah dapat dilihat dari dua sudut pandang yang berbeda yaitu sebagai tujuan pembelajaran dan sebagai pendekatan pembelajaran. Sebagai tujuan berarti pemecahan masalah ditujukan agar siswa dapat merumuskan masalah dari situasi sehari-hari dalam matematika, menerapkan strategi untuk menyelesaikan berbagai masalah dalam matematika maupun dari luar matematika, baik masalah sejenis ataupun masalah lama, menjelaskan hasil yang diperoleh sesuai 
permasalahan asal, mampu menyusun model matematika dan menyelesaikanya untuk masalah nyata dan dapat menggunakan matematika secara bermakna. Sebagai pendekatan pembelajaran berarti pemecahan masalah digunakan untuk menemukan dan memahami materi matematika.

Kemampuan pemecahan masalah merupakan salah satu ranah berfikir tingkat tinggi. Resnick (1987) mengemukakan karakterikstik berfikir tingkat tinggi sebagai berfikir komplek dan non-algoritmik yang memuat:

a. Banyak solusi

b. Bernuansa memutuskan dan menginterpretasi

c. Aplikasi dari berbagai kriteria

d. Ketidaktentuan

e. Pengatuaran diri tentang proses berfikir

f. Penentuan makna, penemuan struktur dalam ketidakberaturan

g. Dan Usaha

Mudrikah (2013) mengemukakan kemampuan pemecahan masalah matematik adalah kemampuan berfikir matematik tingkat tinggi yang memuat aspek-aspek kemampuan untuk:

a. Mengidentifikasi kecukupan data untuk memecahkan masalah

b. Membuat model matematik dari suatu situasi atau masalah sehari-hari dan menyelesaikanya

c. Memilih dan menerapkan strategi untuk menyelesaikan masalah matematika dan atau diluar matematika

d. Menjelaskan atau menginterpretasi hasil sesuai permasalahan asal, serta memeriksa kebenaran hasil atau jawaban.

e. Menerapkan matematika secara bermakna.

Surya (2013) mengemukakan bahwa kemampuan pemecahan masalah adalah kemampuan siswa untuk dapat memahami masalah melalui identifikasi unsur-unsur yang diketahui, ditanyakan, dan kecukupan unsur yang diperlukan, membuat atau menyusun strategi penyelesaian dan merepresentasikan (dengan simbol, gambar, grafik, tabel diagram model dII), Memilih atau menerapkan strategi untuk mendapatkan solusi dan memeriksa kebenararan solusi dan menafsirkanya.

Kirley (2003) mengidentifikasi suatu urutan dasar dari tiga aktifitas kognitif dalam proses pemecahan masalah adalah : 1). Merefresentasikan masalah. berupa pemanggilan kembali konteks, pengetahuan yang bersesuaian, dengan mengidentifikasi tujuan dan kondisi awal yang relevan untuk masalah yang dihadapi. 2). Mencari solusi. meliputi penghalusan tujuan, dan mengembangkan suatu rencana tindakan dalam mencapai tujuan. 3). Mengimplementasikan solusi meliputi eksekusi rencana tindakan dan mengevakuasi hasil.

Soemarmo dan Hendriana , (2014: 23); Lestari (2015: 85), mengemukakan indikator kemampuan penyelesaian masalah matematis adalah sebagai berikut:

1. Mengidentifikasi unsur yang diketahui, ditanyakan, dan kecukupan unsur yang diperlukan.

2. Merumuskan masalah matematis atau menyusun model matematis.

3. Menerapkan strategi untuk menyelesaikan masalah.

4. Menjelaskan atau menginterpretasi hasil penyelesaian masalah.

Menurut Polya (TIM MKPBM, 2001: 84) terdapat empat langkah dalam pemecahan masalah yaitu;

1. Memahami masalah.

2. Merencanakan pemecahan.

3. Menyelesaikan masalah sesuai rencana.

4. Memeriksa kembali hasil yang diperoleh (looking back)

Polya (1973:xvi) mengemukakan proses pada tiap langkah pemecahan masalah melalui pertanyaan berikut: 
Memahami masalah (understanding the problem), diantaranya adalah: 1). apakah yang tidak diketahui?, 2). data apa yang diberikan?, 3). apakah kondisi yang diberikan cukup untuk mencari apa yang ditanyakan?.

Membuat rencana pemecahan (devising a plan). Langkah ini menyangkut beberapa aspek diantaranya sebagai berikut: 1). Teori mana yang dapat digunakan dalam masalah ini?, 2). Perhatikan apa yang ditanyakan?. Atau coba pikirkan soal yang pernah dikenal dengan pertanyaan yang sama. 3). Dapatkan hasil dan metode yang lalu digunakan disini?. 4). Apakah semua data dan kondisi sudah digunakan?, 5). Sudahkan diperhitungkan ide-ide penting yang akan digunakan dalam soal tersebut?

Melakukan perhitungan (carrying out the plan). langkah ini ditekankan pada pelaksanaan rencana penyelesaian. Prosedur yang ditempuh adalah: 1). Memeriksa setiap langkah apakah sudah benar atau belum?, 2). Bagaimana membuktikan bahwa langkah yang dipilih sudah benar?.

Memeriksa kembali proses dan hasil (looking back) pada bagian akhir. Polya menekankan pada bagaimana cara memeriksa kebenaran jawaban. Prosedur yang harus diperhatikan adalah: 1). Dapatkah diperiksa sanggahanya?, 2). Dapatkah jawaban tersebut dicari dengan cara lain?.

\section{Indikator, Soal dan Rublik skoring soal Pemecahan Masalah Matematis.}

Kejelasan dalam pembuatan indikator pemecahan masalah telah meningkatkan kualitas penilaian (Wiggins, 1990). Begitu pula Rubrik skoring yang komprehensif dalam menilai kemampuan pemecahan masalah matematika siswa akan dapat mengukur penguasaan konsep, prosedur, proses, dan disposisi siswa terhadap matematika (Sanchez et al., 2002). Hal Ini telah mematahkan penggunaan penilaian tradisional yang selama ini hanya berdasarkan kebenaran jawaban siswa (Van de Walle et al., 2009). Sebuah rubrik skoring yang dikembangkan dengan baik akan dapat memberikan informasi yang valid kepada guru dan dapat mengukur kemajuan siswa dalam pengetahuan, dan proses tertentu (Van de Walle et al., 2009). Berdasarkan informasi dari rubrik tersebut, guru dapat memantau pembelajaran siswa dan memberikan beberapa masukan sehingga siswa dapat merestrukturisasi pengetahuannya (Anderson \& Puckett, 2003).

Rubrik skoring adalah komponen kunci dalam penilaian otentik. Rubrik ini didasarkan pada ukuran kriteria yang direferensikan (Reynolds, Livingston, \& Willson, 2009). Dengan kriteria interpretasi yang direferensikan, Reynolds dkk. menegaskan bahwa siswa dinilai tingkat kinerjanya dalam rubrik berdasarkan pada apa yang mereka tahu atau apa yang bisa mereka lakukan. Rubrik holistik, analitik, proses, dan anaholitik adalah beberapa rubrik penilaian yang biasanya digunakan oleh komunitas praktik (Kulm, 1994). Masing-masing rubrik ini menyajikan berbagai cara mengevaluasi tingkat pemahaman siswa. Misalnya, anaholistik adalah rubrik kombinasi analitis dan holistik, yang didasarkan pada beberapa kriteria yang mencakup keseluruhan pengetahuan konseptual dan prosedural siswa (Kulm, 1994; Reynolds et al., 2009). Rubrik anaholistik adalah alat penilaian yang tepat untuk menilai pemecahan masalah karena memberikan penilaian menyeluruh terhadap jangkauan luas pembelajaran matematis (Kulm, 1994). Ini adalah pendekatan penilaian untuk mencetak sebuah tugas matematika berdasarkan banyaknya kriteria dalam pengetahuan konseptual dan prosedural keseluruhan siswa serta proses pemecahan masalah. Skor dalam setiap kriteria dapat disimpulkan untuk mendapatkan titik total sebagai indikator kemampuan siswa.

Pemecahan masalah memiliki sejarah panjang dalam penelitian pendidikan matematika. Berdasarkan George Polya, dokumen NCTM menyarankan guru untuk menilai proses berpikir kompleks siswa Melalui 
tugas pemecahan masalah yang meliputi pemahaman masalah, perencanaan strategi, pelaksanaan solusi, dan melihat kembali solusi (NCTM, 1989, 1991, 1995, 2000). Indikator soal pemecahan masalah dapat dibuat pada satu soal pemecahan masalah atau dapat pula seluruh indikator pemecahan masalah terdapat pada satu soal. Hal itu bergantung pada kemampuan pembuat soal dalam merangkai soal untuk diaplikasikan. Adapun tabel 1 menunjukan sebuah soal memiliki satu indikator pemecahan masalah.

\section{Tabel 1. Contoh Indikator dan butir soal kemampuan pemecahan masalah matematis SMP}

\begin{tabular}{|c|c|c|}
\hline $\begin{array}{l}\text { Indikator Pemecahan } \\
\text { Masalah Matematis }\end{array}$ & Butir soal & Skor \\
\hline $\begin{array}{lr}\text { Mengidentifikasi } & \text { unsur- } \\
\text { unsur yang diketahui, } \\
\text { ditanyakan r dan }\end{array}$ & $\begin{array}{l}\text { Seorang petani mempunyai sebidang tanah berbentuk persegi panjang. } \\
\text { Lebar tanah tersebut } 6 \mathrm{~m} \text { lebih pendek daripada panjangnya. Diketahui } \\
\text { keliling tanah } 60 \mathrm{~m} \text {. Cukupkah informasi di atas untuk menentukan luas }\end{array}$ & 2 \\
\hline $\begin{array}{l}\text { kecukupan unsur yang } \\
\text { diperlukan }\end{array}$ & $\begin{array}{l}\text { tanah? Kalau cukup selesaikanlah masalah tersebut. Kalau tidak cukup, } \\
\text { lengkapi kemudian selesaikan. }\end{array}$ & \\
\hline $\begin{array}{lr}\text { Merumuskan } & \text { masalah } \\
\text { matematik } & \text { atau } \\
\text { menyusun } & \text { model } \\
\text { matematik } & \end{array}$ & $\begin{array}{l}\text { Diketahui harga sepasang sepatu dua kali harga sepasang sandal. } \\
\text { Seorang pedagang membeli } 4 \text { pasang sepatu dan } 3 \text { pasang sandal. } \\
\text { Pedagang tersebut harus membayar Rp. } 275.000,00 \text {. Buatlah model } \\
\text { matematika dari keterangan tersebut, kemudian selesaikan! }\end{array}$ & 2 \\
\hline $\begin{array}{l}\text { Menerapkan strategi } \\
\text { untuk menyelesaikan } \\
\text { masalah sehari-hari }\end{array}$ & $\begin{array}{l}\text { Sketsa sebuah meja berbentuk persegi panjang dengan panjang } 16 \mathrm{x} \mathrm{cm} \\
\text { dan lebar I0x cm. Luas perrnukaan meja tidak kurang dari } 40 \mathrm{dm}^{2} \text {. } \\
\text { Tentukan ukuran minimum permukaan meja tersebut! Jelaskan cara } \\
\text { memperoleh jawaban tersebut. }\end{array}$ & 2 \\
\hline $\begin{array}{l}\text { Menjelaskan atau } \\
\text { menginterpretasikan hasil } \\
\text { sesuai permasalahan } \\
\text { awal }\end{array}$ & $\begin{array}{l}\text { Harga } 1 \text { lusin pensil adalah Rp18.000,00. } \\
\text { a. Berapakah harga } 1 \text { buah pensil? Jelaskan cara menghitungnya } \\
\text { b. Berapakah harga } 5 \text { buah pensil? Jelaskan cara menghitungnya }\end{array}$ & 2 \\
\hline $\begin{array}{l}\text { Menggunakan } \\
\text { matematika } \\
\text { bermakna }\end{array}$ & $\begin{array}{l}\text { Pak Putu memperoleh gaji Rp950.000,00 sebulan bermakna dengan } \\
\text { penghasilan tidak kena pajak Rp. } 380.000,00 \text { Andaikan pajak penghasilan } \\
\text { (PPh) ditetapkan 10\%, berapakah besar gaji yang diterima Pak Putu Per } \\
\text { bulan? }\end{array}$ & 2 \\
\hline
\end{tabular}

Sumber: Diadaptasi dari Rosalina, D (2016)

Tabel 2. Rublik skoring soal pemecahan masalah

\begin{tabular}{|c|c|c|c|c|}
\hline Skor & Memahami & $\begin{array}{l}\text { Membuat Rencana } \\
\text { Pemecahan }\end{array}$ & $\begin{array}{l}\text { Melakukan } \\
\text { perhituingan }\end{array}$ & $\begin{array}{l}\text { Memeriksa } \\
\text { kembali }\end{array}$ \\
\hline 0 & $\begin{array}{l}\text { Salah } \\
\text { menginterpretasi } \\
\text { atau salah sama } \\
\text { sekali }\end{array}$ & $\begin{array}{l}\text { Tidak ada rencana atau } \\
\text { membuat rencana yang } \\
\text { tidak relevan }\end{array}$ & $\begin{array}{l}\text { Tidak melakukan } \\
\text { perhitungan }\end{array}$ & $\begin{array}{l}\text { Tidak ada } \\
\text { pemeriksaan atau } \\
\text { keterangan lain }\end{array}$ \\
\hline 1 & $\begin{array}{l}\text { Salah } \\
\text { menginterpretasi } \\
\text { sebagian soal dan } \\
\text { mengabaikan } \\
\text { kondisi soal }\end{array}$ & $\begin{array}{l}\text { Membuat rencana } \\
\text { pemecahan yang tidak } \\
\text { dapat dilaksanakan, } \\
\text { sehingga tidak dapat } \\
\text { dilaksanakan }\end{array}$ & $\begin{array}{l}\text { Melaksanakan } \\
\text { prosedur yang benar } \\
\text { dan mungkin } \\
\text { menghasilkan jawaban } \\
\text { yang benar tetapi } \\
\text { salah perhitungan } \\
\end{array}$ & $\begin{array}{l}\text { Ada pemeriksaan } \\
\text { tetapi tidak tuntas }\end{array}$ \\
\hline 2 & $\begin{array}{l}\text { Memahami masalah } \\
\text { soal selengkapnya }\end{array}$ & $\begin{array}{l}\text { Membuat rencana yang } \\
\text { benar tetapi salah dalam }\end{array}$ & $\begin{array}{l}\text { Melakukan proses } \\
\text { yang benar dan }\end{array}$ & $\begin{array}{l}\text { Pemeriksaan } \\
\text { dilakukan untuk }\end{array}$ \\
\hline
\end{tabular}




\begin{tabular}{llll}
\hline & $\begin{array}{l}\text { hasil atau tidak ada } \\
\text { hasilnya }\end{array}$ & $\begin{array}{l}\text { mendapatkan hasil } \\
\text { yang benar }\end{array}$ & $\begin{array}{l}\text { melihat kebenaran } \\
\text { proses }\end{array}$ \\
\hline 3 & $\begin{array}{l}\text { Membuat rencana benar } \\
\text { tetapi belum lengkap }\end{array}$ & \\
\hline 4 & $\begin{array}{l}\text { Membuat rencana sesuai } \\
\text { dengan prosedure dan } \\
\text { mengarah pada solusi } \\
\end{array}$ & \\
& yang benar & \\
\hline Skor & 2 & 4 & 2 \\
\hline
\end{tabular}

Cara penilaian diatas dapat dilakukan pada satu

buah soal yang memiliki karakteristik soal pemecahan masalah lengkap atau pada satu soal yang hanya memuat satu indikator dari soal pemecahan masalah matematis.

\section{KESIMPULAN}

1. Kemampuan pemecahan masalah matematis adalah kemampuan seseorang dalam menyelesaikan masalah matematis non-routin yang disajikan dalam bentuk soal matematika tekstual maupun kontekstual yang dapat mengukur kemampuan siswa dalam menyelesaikan masalah

2. Indikator kemampuan pemecahan masalah secara garis besar adalah mampu memahami masalah, merencanakan penyelesaian, melakukan perhitungan dan mengecek kembali hasil perhitungan.

3. Pembuatan soal kemampuan pemecahan masalah dapat dilakukan dengan cara satu soal memuat semua karakteristik pemecahan masalah atau tiap item indikator dibuat dalam satu soal terpisah.

\section{REKOMENDASI}

Informasi pada artikel ini dapat dijadikan rujukan bagi peneliti dan mahasiswa untuk penilaian kemampuan pemecahan masalah matematis siswa SMP

\section{DAFTAR PUSTAKA}

Anderson, J. (2009). Mathematics curriculum development and the role of problem solving. ACSA Conference 2009, 1-8. Retrieved from http://www.acsa.edu.au/pages/images/judy anderson- mathematics curriculum development.pdf

Anderson, R. S., \& Puckett, J. B. (2003). Assessing students' problem-solving assignments. New Directions for Teaching and Learning, (95), 81-87. http://dx.doi.org/10.1002/tt.117

Armanto, Dian. (2002). Teaching Multiplication and Division Realistically in Indonesian Primary Schools : A Prototype of Local Instructional Theory. Disertasion. Enschede: Print Partnersip skamp.

Depdiknas, P. K. B. (2007). Naskah akademik kajian kebijakan kurikulum Pendidikan Kewarganegaraan. Jakarta: Pusat Kurikulum Balitbang Depdiknas.

Kirley, J (2003). Principles for teaching _problem solving. [online. Tersedia: www. plato.com/download/papers/paper 04.pdf diakses pada tanggal 12 mei 2010. 
Kulm, G. (1994). Mathematics Assessment. What Works in the Classroom. Jossey-Bass Inc., Publishers, 350 Sansome Street, San Francisco, CA 94104.

Kulm, G. (1994). Mathematics assessment: What works in the classroom. San Francisco, CA: Jossey Bass Inc.

Lestari, P. D. (2015). Keefektifan Model ProblemBased Learning Dengan Pendekatan Saintifik terhadap Kemampuan Pemecahan Masalah Matematis Dan Kemandirian Belajar Peserta Didik Kelas VII (Doctoral dissertation, UNIVERSITAS NEGERI SEMARANG).

Machmul, Tedy (2013). Peningkatan kemampuan komunikasi, pemecahan masalah matematis dan self- efficasy siswa smp melalui pendekatan problem-centered learning dengan stategi scaffolding. Bandung: Disertasi UPI tidak diterbitkan.

Montague, M. (2007). Self-regulation and mathematics instruction. Learning Disabilities Research \& Practice, 22(1), 75-83.

Mudrikah, Achmad (2013). Pembelajaran barbasisrnasalah berbantuan komputer untuk meningkatkan kemampuan komunikasi, pemecahan masalah, dan disposisi matematik siswa sekolah menengah atas. Bandung: Disertasi UPI tidak diterbitkan.

Nasional Council of Teacher of Mathematics(NCTM). (2000). Prinsiple and standards for school mathematics. Reston. VA: NCTM

National Council for Teachers of Mathematics. (1995). Assessment standards for school mathematics. Reston, VA: NCTM.

National Council of Teachers of Mathematics. (1989). Curriculum and evaluation standards for school mathematics. Reston, VA: NCTM

National Council of Teachers of Mathematics. (1991). Professional standards for teaching mathematics. Reston, VA: NCTM.

National Council of Teachers of Mathematics. (2000). Principles and standards for school mathematics. Reston, VA: NCTM.

Polya, G. 1973, How To Solve It. New Jersey: Princeton University Press

Resnick, L.B(1987). Educational and learning to think. [online. Tersedia: the national academies press at: http ://www.nap. edtileatalo g/1032. htmir 7 februari 2011].
Reynolds, C. R., Livingston, R. B., \& Willson, V. (2009). Measurement and assessment in education (2nd ed.). Boston, MA: Pearson.

Rosalina D. (2016). Penerapan Pembelajaran Inkuiri Terbimbing Terhadap Kemampuan Pemecahan Masalah Masalah dan Koneksi Matematik Siswa SMP ditinjau dari tingkat Kecemasan Matematika. Tesis Pada Pascasarjana STKIP Siliwangi, Bandung: Tidak dipublikasikan.

Sánchez, J. C., Encinas, L. H., Fernández, R. L., \& Sánchez, M. R. (2002). Designing hypermedia tools for solving problems in mathematics. Computers \& Education, 38(4), 303-317.

Sato, Manabu (2007). Tantangan yang Harus Dihadapi Sekolah, makalah dalam Bacaan Rujukan untuk Lesson Study Berdasarkan Pengalaman Jepang dan IMSTEP. Jakarta: Sisttems

Soemarmo, U dan Hendriana, H. (2014). Penilaian Pembelajaran Matematika. Bandung: PT Refika Aditama

Sugiman, Kusumah, S., \& Sabandar, J. (2012). Pemecahan Masalah Matematik dalam Matematika Realistik, 2, 1-10.

Suharta, I. G. P., \& Putu, G. (2002). Matematika Realistik: Apa dan Bagaimana. Jurnal Pendidikan dan Kebudayaan, 38(8), 641-652.

Sumarmo, U. (2005). Pengembangan Berfikir Matematik Tingkat Tinggi Mahasiswa SLTP dan SMU serta Mahamahasiswa Strata Satu (S1) Melalui Berbagai Pendekatan Pembelajaran. Laporan Penelitian Hibah Penelitian Tim Pascasarjana-HTPT Tahun Ketiga. Bandung:Tidak diterbitkan

Surya, edy. (2013). Peningkatan kemampuan representasi visual thinking pada pemecahan masalah matematis dan kemandirian belajar siswa smp melalui pembelajaran kontekstual. Bandung: Disertasi UPI tidak diterbitkan.

Tim MKPBM. 2001. Strategi Belajar Mengajar Kontemporer. Universitas Pendidikan Indonesia (UPI), Bandung.

Van de Walle, J. A., Karp, K. S., \& Bay Williams, J. M. (2009). Elementary and middle school mathematics: Teaching developmentally (7th ed.). Boston, MA: Allyn \& Bacon/Merill. 
Wiggins, G. (1990). The case for authentic assessment. Retrieved from ERIC database (ED328611).

Zulkardi. 2005. "RME suatu Inovasi dalam Pendidikan Matematika di Indonesia".situswww. pmri.or.id. 